\title{
Permainan Playdoh dalam Peningkatan Kreativitas Anak
}

\author{
${ }^{1}$ Mario Erick Wantah, ${ }^{2}$ Siti Fathimah \\ ${ }^{1}$ Fakultas Ilmu Pendidikan, Universitas Negeri Manado \\ ${ }^{2}$ Fakultas Ilmu Sosial, Universitas Negeri Manado \\ ${ }^{1}$ mariowantah@unima.ac.id, ${ }^{2}$ sitifathimah@unima.ac.id
}

\begin{abstract}
Abstrak. Pendidikan berkualitas yang ditanamkan kepada anak semenjak usia dini merupakan salah satu kunci untuk membentuk manusia yang berkualitas baik mental maupun intelektual yang salah satunya dapat diraih melalui pengembangan kreativitas dengan menggunakan permaian Playdoh. Tujuan penelitian ini adalah mendeskripsikan bagaimana permainan Playdoh dapat meningkatkan kreativitas anak di TK GMIM Bethesda Sawangan. Penelitian ini merupakan jenis penelitian tindakan kelas dengan pelaksanaan dua siklus yang dilaksanakan di TK GMIM Bethesda Sawangan, Kabupaten Minahasa Utara yang beralamat di Desa Sawangan. Subjek pada penelitian tindakan kelas ini adalah anak-anak di TK GMIM Bethesda Sawangan, Kelompok B Semester II tahun pelajaran 2019/2020 yang terdiri dari 24 anak (9 anak laki-laki dan 15 anak perempuan dengan usia 4-6 tahun). Hasil penelitian menunjukkan bahwa bermain playdoh di TK GMIM Bethesda Sawangan tahun pelajaran 2019/2020 dapat meningkatkan kreativitas anak. Hal ini dibuktikan dengan adanya peningkatan hasil persentase kreativitas anak baik dalam siklus I maupun siklus II. Hasil tersebut dapat dilihat pada siklus I total rata-rata sebanyak 18,46 (75,58\%) meningkat dan menjadi 20,6 (93,57\%) pada siklus II. Secara umum, peningkatan kreativitas anak melalui permainan playdoh dapat terlaksanan dengan efektif dan menunjukkan peningkatan yang positif.
\end{abstract}

Kata Kunci: kreativitas, playdoh, bermain, pendidikan anak usia dini

Abstract. Quality education that is instilled in children from an early age is one of the keys to forming a quality human being both mentally and intellectually, one of which can be achieved through developing creativity using Playdoh games. The purpose of this research is to describe how the Playdoh game can increase children's creativity at GMIM Bethesda Sawangan Kindergarten. This research is a type of classroom action research with the implementation of two cycles carried out at GMIM Bethesda Sawangan Kindergarten, North Minahasa Regency, which is located at Sawangan Village. The subjects in this classroom action research were children in TK GMIM Bethesda Sawangan, Group B Semester II of the 2019/2020 academic year consisting of 24 children (9 boys and 15 girls aged 4-6 years). The results showed that playing playdoh at TK GMIM Bethesda Sawangan in the 2019/2020 academic year could increase children's creativity. This is evidenced by an increase in the percentage of children's creativity in both cycle I and cycle II. These results can be seen in the first cycle the total average of 18.46 (75.58\%) increased and became 20.6 (93.57\%) in the second cycle. In general, increasing children's creativity through playdoh games can be carried out effectively and show positive improvements.

Keywords: creativity, playdoh, play, early childhood education

\section{PENDAHULUAN}

Anak memiliki banyak potensi pada masing-masing bentuk perkembangan. Agar dapat mengoptimalkan potensi pada tiap-tiap perkembangan anak, maka anak harus difasilitasi dalam wadah yang tepat, yakni pendidikan yang tepat (Hazhira Qudsyi, 2010). Pendidikan ini tidak semata pendidikan secara formal saja, namun juga termasuk di dalamnya adalah pendidikan dalam keluarga, pendidikan dalam masyarakat, dan tentunya pendidikan secara formal pada suatu lembaga pendidikan.

Pendidikan berkualitas yang ditanamkan kepada anak semenjak usia dini merupakan salah satu kunci untuk membentuk manusia 
yang berkualitas baik mental maupun intelektual. Karena karakter dan kecerdasan seseorang sangat dipengaruhi oleh pendidikan yang didapat sejak ia masih kecil, dan pengalaman masa kecilnya akan sangat berpengaruh untuk bekal kehidupan hingga ia dewasa nanti.

Anak tidak berkembang secara otomatis, namun dipengaruhi oleh cara lingkungan memperlakukan mereka. Ketika anak memasuki lingkungan sekolah non formal seperti taman kanak-kanak, maka ruang dan kesempatan untuk berinteraksi semakin luas (Wisjnu Martani, 2012).

Secara eksplisit pada setiap perkembangan anak dan setiap jenjang pendidikan bahwa kreativitas perlu dipupuk, dikembangkan, ditingkatkan disamping mencerdaskan. Dengan memberikan lingkungan yang merangsang perkembangan, dapat membantu anak dalam meningkatkan potensi yang dimilikinya (Khamim Zarkasih Putro, 2016).

Ahmad Susanto (2013:102-103), berpendapat bahwa komponen kreativitas sedikitnya meliputi fluency (kelancaran), flexibility (keluwesan), dan originality (kebaruan). Pertama keterampilan berpikir lancar, ciri-cirinya yaitu ,memberikan banya cara/saran untuk melakukan berbagai hal, mencetuskan banyak gagasan, selalu memikirkan lebih dari satu jawaban, keterampilan ini ditunjukan oleh perilaku anak, seperti bekerja lebih cepat melakukan lebih banyak dari anak-anak lain, dapat dengan cepat melihat kesalahan atau kekurangan dari suatu objek/situasi.

Kedua, keterampilan berpikir luwes, ciricirinya yaitu menghasilkan gagasan, dapat melihat masalah dari sudut pandang berbeda, mencari berbagai alternatif, dan mampu mengubah cara pemikiran. keterampilan ini ditunjukan oleh perilaku anak, seperti membuat bentuk dengan konsep yang berbeda, mampu mengubah arah berpikir secara spontan, memikirkan macam-macam cara yang berbeda untuk menyelesaikan masalah.

Ketiga, keterampilan berpikir orisinal, yaitu mampu mengungkap hal yang unik, memikirkan cara yang tidak lazim untuk mengungkapkan diri.keterampilan ini ditunjukan oleh perilaku anak seperti, memikirkan bentuk-bentuk yang orang lain tidak terpikirkan sama sekali, berusaha membuat suatu bentuk yang baru, cara berpikir yang berbeda dengan orang lain, menggunakan pendekatan terbaru.

Sentra seni di Taman Kanak-kanak merupakan salah satu dari bidang pengembangan kemampuan dasar yang dipersiapakan oleh guru untuk meningkatkan kemampuan dan kreativitas anak sesuai dengan tahap perkembangannya. Sentra seni memiliki fokus memberikan kesempatan pada anak untuk mengembangkan berbagai keterampilan, terutama keterampilan tangan dengan menggunakan berbagai bahan dan alat, seperti melipat, menggunting, mewarnai, membuat prakarya, melukis dan membuat prakarya dengan menggunakan adonan (Ummi Kalsum, 2016). Pada sentra ini, anak bermain sambil belajar mengasah kerapian, kemandirian, kreativitas serta tanggung jawab, sehingga kreativitas belajar anak melalui sentra seni ini akan meningkat.

Namun terkadang kreativitas anak dapat terhambat karena kurangnya latihan dan kurangnya imajinasi anak dalam membentuk, sehingga antusiasme anak dalam berkreasi menjadi berkurang. Permasalahan tersebut juga timbul pada kegiatan membentuk di area seni TK GMIM Bethesda Sawangan. Berdasarkan hasil observasi yang dilakukan di TK GMIM Bethesda Sawangan Tahun ajaran 2019/2020 pada semester genap, diketahui bahwa kegiatan membentuk di area seni masih dihadapkan pada kendala. Hal ini disebabkan oleh beberapa faktor, salah satunya yaitu kurangnya latihan dalam membentuk dan keterbatasan media pembelajaran yang akan digunakan pada proses pembelajaran berikutnya, sehingga anak tidak dapat mengapresiasikan karyanya dengan baik. Selain itu, respon anak selama proses pembelajaran pada kegiatan membentuk di area seni dinilai masih kurang, karena sebagian anak tidak terlalu antusias dengan media yang digunakan pada proses pembelajaran.

Anak didik banyak yang terlihat bosan, ngantuk, kurang tertarik, dan bahkan ada yang main sendiri saat mengerjakan ketrampilan 
seperti menggambar, mewarnai, menciplak, menggunting atau ketrampilan lainnya. Padahal jika anak tidak bosan mengerjakan ketrampilan, hasil karya anak dapat meningkatkan kecerdasan visual spasial anak. Dengan keterampilan tangan anak dapat memanipulasi bahan, kreativitas dan imajinasi anak pun terlatih karenanya. Selain itu kerajinan tangan dapat membangun kepercayaan diri anak (Sujiono, 2008:6).

Berbagai strategi dapat digunakan untuk mengoptimalkan kegiatan membentuk di area seni, yaitu dengan menggunakan media yang baik agar kreativitas anak dapat meningkat. Salah satunya melalui pemanfaatan perkembangan tekonologi melalui akun google document (Fathimah, Sidik, and Rahman 2020), dimana pemanfaatan teknologi dapat mendukung bagi kelancaran dalam proses belajar mengajar. Begitu juga dengan media pembelajaran berupa mainan edukatif yang merupakan salah satu media yang dapat mengembangkan kreativitas dalam bermain. Salah satu media pembelajaran yang dapat diterapkan dalam meningkatkan kreativitas anak adalah permainan Playdoh. Berikut merupakan sintaks permainan Playdoh.

\section{Tabel 1 Sintaks Permainan Playdoh}

\begin{tabular}{|c|c|c|}
\hline No & $\begin{array}{c}\text { Lingkup } \\
\text { Perkembangan }\end{array}$ & Kegiatan \\
\hline 1 & $\begin{array}{l}\text { Nilai Agama dan } \\
\text { Moral }\end{array}$ & $\begin{array}{l}\text { Menyebutkan bahwa semua yang ada di alam semesta adalah } \\
\text { ciptaan Tuhan (termasuk manusia yang membuat mainan } \\
\text { Playdoh) }\end{array}$ \\
\hline 2 & Sosial Emosional & $\begin{array}{ll}- & \text { Mematuhi tata tertib ketika mengambil playdoh } \\
\text { - } & \text { Kemandirian dalam membuat bentuk (playdoh) } \\
\text { - } & \text { Kerjasama ketika bekerja secara kelompok }\end{array}$ \\
\hline 3 & Bahasa & $\begin{array}{l}\text { Menyebutkan jenis/model/nama dari hasil karya tersebut } \\
\text { - } \\
\text { Menulis nama hasil karya tersebut Menceritakan tentang } \\
\text { hasil karya } \\
\text { Menghubungkan tulisan dengan hasil karya. Contoh hasil } \\
\text { karya kue dengan tulisan kue }\end{array}$ \\
\hline 4 & Kognitif & $\begin{array}{ll}- & \text { Menghitung hasil karya } \\
\text { - } & \text { Membuat urutan bilangan dengan mainan Playdoh } \\
\text { - } & \text { Mengelompokan hasil karya sesuai dengan bentuknya } \\
\text { - } & \text { Mengurutkan hasil karya dari yang kecil sampai yang besar } \\
\text { - } & \text { Mengelompokan hasil karya berdasarkan warna } \\
& \text { Membuat penambahan dan pengurangan dengan hasil karya }\end{array}$ \\
\hline 5 & Fisik Motorik & 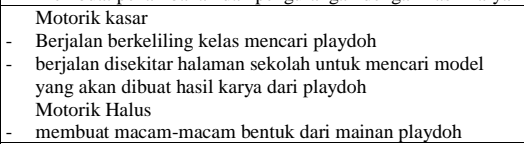 \\
\hline 6 & Seni & $\begin{array}{ll}- & \text { membuat bentuk dari mainan playdoh } \\
- & \text { Menyanyi tentang bentuk karya yang dibuat }\end{array}$ \\
\hline
\end{tabular}

\section{(Sumber: Modifikasi Peneliti)}

Dengan permainan playdoh anak bisa menciptakan berbagai bentuk sesuka hati mereka tanpa diberi contoh yang konkrit berupa gambar atau benda riil, karena anakanak akan membayangkan sendiri semua jenis bentuk yang dikatakan oleh gurunya, dengan hasil ciptaan sendiri mereka akan bisa mengamati secara langsung pada keadaan yang sebenarnya, sehingga kreativitasnya akan lebih terarah dan lebih baik.

Kegiatan bermain Playdoh bisa mengembangkan kemampuan motorik, salah satu unsur kemampuan motorik halus yang sangat penting untuk distimulasi yaitu keterampilan dalam menggunakan jari tangan (Wikaningtyas, 2014), dan juga dapat mengetahui arti berusaha dan melatih kesabaran anak. Jadi anak tidak hanya berkembang dalam motoriknya tetapi juga mengembangkan sosial emosinya secara keseluruhan begitu juga aspek perkembangan yang lainnya. Playdoh juga dapat meningkatkan kreativitas anak karena dilaksanakan dengan proses belajar yang menyenangkan dan membuat kegiatan bermain yang dilakukan tanpa memaksa anak dan sesuai dengan usia anak.

Playdoh dipilih karena mudah didapat, dan sangat aman bagi anak. Selain itu guru TK GMIM Bethesda Sawangan, belum pernah menggunakan Playdoh sebagai media dalam pembelajaran membentuk. Kelebihan Playdoh daripada plastisin yang lain yaitu selain aman dan mudah dibersihkan karena tidak terlalu berminyak seperti plastisin yang biasa, sehingga anak bisa fokus diharapkan dapat mengapresiasi karyanya dengan baik. Berdasarkan rumusan masalah, maka tujuan yang ingin dicapai dalam penelitian ini adalah mendeskripsikan bagaimana permainan Playdoh dapat meningkatkan kreativitas anak di TK GMIM Bethesda Sawangan.

\section{METODE PENELITIAN}

Penelitian ini menggunakan pendekatan kualitatif, yang prosedur penelitiannya menghasilkan data deskriptif berupa kata-kata tertulis atau lisan dari orang-orang dan perilaku. Dilihat dari tujuan penelitian ini, maka penelitian ini termasuk jenis tindakan kelas. Rancangan penelitian yang diggunakan dalam penelitian ini adalah rancangan penelitian tindakan kelas (PTK) dengan dua siklus. Alasan PTK dipilih karena penelitian ini digunakan untuk melakukan perbaikan 
dalam berbagai aspek yang muncul di dalam kelas dengan terperinci, dimulai dari observasi awal sampai pemilihan model pembelajaran yang sesuai dengan permasalahan yang muncul saat kegiatan pembelajaran.

Penelitian Tindakan Kelas ini dilaksanakan di TK GMIM Bethesda Sawangan, Kabupaten Minahasa Utara yang beralamat di Desa Sawangan. Penelitian ini dilakukan pada anak kelompok B tentang permainan playdoh untuk meningkatkan kreativitas anak semester genap tahun ajaran 2019/2020. Subjek pada penelitian tindakan kelasi ini adalah anak-anak di TK GMIM Bethesda Sawangan, Kelompok B Semester II tahun pelajaran 2019/2020 dengan jumlah anak 24 anak, yang terdiri dari 9 anak laki-laki dan 15 anak perempuan dengan usia 4-6 tahun.

Dalam peneltian tindakan kelas ini pengumpulan data dilakukan oleh peneliti dibantu guru kelas dan teman kolaboratif, yang meliputi data proses dan data hasil kreativitas dengan menggunakan permainan playdoh. Data-data pada proses pembelajaran berupa data perencanaan dan data pelaksanaan pembelajaran, sedangkan untuk data hasil adalah dokumentasi hasil kreativitas anak. Perencanaan berupa data persiapan mengajar yang dibuat secara kolaboratif, adapun data perencanaan tersebut meliputi rumusan tujuan, kegiatan pembelajaran termasuk materi yang diggunakan dalam pembelajaran.

Data dibuat dan terkumpul sebelum kegiatan pelaksanaan pembelajaran. Prosedur pengumpulan data secara kolaboratif dilakukan saat kegiatan pembelajaran, dengan guru kelas yang sedang melakukan kegiatan pembelajaran, peneliti dan teman kolaboratif bertindak sebagai pengamat. Data dikumpulkan dengan berbagai teknik, seperti observasi, wawancara, catatan harian, dan angket.

\section{HASIL DAN PEMBAHASAN}

\section{a. Hasil}

\section{a) Temuan Siklus I}

Pada siklus I keterlaksanaan pembelajaran dengan menggunakan playdoh secara keseluruhan berjalan dengan baik, mulai dari kegiatan awal, kegiatan inti sampai kegiatan penutup, anak aktif dalam mengikuti kegiatan pembelajaran dengan menggunakan playdoh. Pada waktu guru mengeluarkan playdoh, anakanak begitu senang karena mereka sudah lama tidak bermain mainan lilin. Plastisin yang terakhir digunakan diprotes oleh orang tua murid karena mereka melihat berita di TV bahwa plastisin menggunakan campuran bahan berbahaya yang tidak bagus untuk kesehatan. Anak-anak merasa senang karena mereka dapat bermain, berkomunikasi dan bekerjasama dengan teman-temannya, membuat suatu bentuk playdoh dengan imajinasi yang ada dalam pikiran mereka.

Ketika anak-anak membuat hasil karya dari playdoh, anak sudah melatih motorik halusnya dengan keterampilan jari-jari, membuat karya seni berupa hewan, tumbuhan dan benda-benda lain yang merupakan ciptaan Tuhan Yang Maha Esa, disini anak mengembangkan nilai agama dan moral. Mengembangkan kognitif anak melalui belajar berhitung dengan playdoh, mengelompokan jenis hasil karya, warna dan ukuran, membuat kelompok dari karya yang paling besar sampai yang paling kecil, menceritakan tentang karya yang telah dibuat, membuat penambahan dan pengurangan dengan playdoh, melatih imajinasi dan kreativitas anak melalui membuat karya/bentuk dari playdoh. Dalam lingkup perkembangan sosial emosional, anak belajar saling membantu sesama teman, mematuhi peraturan yang ada, berkomunikasi dengan semua teman tidak hanya teman dekat yang selalu diajak berbicara dan bermain, menghargai pendapat orang lain ketika salah satu teman sedang menceritakan tentang hasil karya yang dibuatnya. Untuk lingkup perkembangan bahasa, anak-anak menyebutkan nama-nama dari hasil karya yang telah dibuatnya, bercerita tentang bentuk karya yang dibuat. Sedangkan untuk lingkup perkebangan seni, anak dapat berkreasi dengan playdoh dengan membuat macam-macam bentuk sesuai dengan ide dan imajinasi yang ada dalam diri anak.

Peran playdoh untuk meningkatkan kreativitas anak ternyata juga sangat menunjang proses belajar mengajar ke arah positif. Hal ini ditunjukan dengan data hasil 
observasi aktivitas belajar anak pada pertemuan pertama dan kedua seecara keseluruhan bisa dilihat pada kegiatan awal, yaitu mengikuti kegiatan berdoa sebelum kegiatan, kegiatan percakapan tentang playdoh, kegiatan motorik kasar, kemudian kegiatan inti yang terdiri dari kegiatan mengamati playdoh, tanya jawab, mengumpulkan informasi tentang playdoh, menalar, mengkomunikasikan, mengerjakan kegiatan yang disiapkan dalam kelompok kecil, serta pada kegiatan akhir yaitu berdiskusi serta berdoa, pada pertemuan pertama mendapat skor rata-rata 17,28 dengan prosentase $73,81 \%$, sedangkan pada pertemuan kedua mendapat skor rata-rata 19,92 dengan prosentase $80,05 \%$. Artinya aktivitas anak secara keseluruhan apabila di rata-rata mendapat skor 18,6 dengan prosentase $75,93 \%$ siswa aktif melaksanakan aktivitas belajar.

Pengunaan playdoh untuk meningkatkan kreativitas dapat membantu anak dalam proses belajar mengajar. Hal ini ditunjukan dari data observasi hasil belajar anak selama pelaksanaan tindakan siklus I, pertemuan pertama secara keseluruhan untuk lingkup perkembangan nilai agama dan moral mendapat skor rata-rata 22 dengan prosentase $91,66 \%$, sosial emosional mendapat skor ratarata 13 dengan prosentase 54,16\%, kognitif mendapat skor rata-rata 22 dengan prosentase $83,33 \%$, bahasa mendapat skor rata-rata 18 dengan prosentase $75 \%$, fisik motorik mendapat skor rata-rata 24 dengan prosentase $100 \%$, dan seni mendapat skor rata-rata 12 dengan prosentase $50 \%$. Sedangkan untuk pertemuan kedua, secara keseluruhan untuk untuk lingkup perkembangan nilai agama dan moral mendapat skor rata-rata 23 dengan prosentase $100 \%$, sosial emosional mendapat skor rata-rata 19 dengan prosentase $82,60 \%$, kognitif mendapat skor rata-rata 22 dengan prosentase $95,65 \%$, bahasa mendapat skor rata-rata 20 dengan prosentase $86,95 \%$, fisik motorik mendapat skor rata-rata 23 dengan prosentase $100 \%$, dan seni mendapat skor ratarata 19 dengan presentase $82,60 \%$.

Penggunaan playdoh dalam pembelajaran di kelas dapat meningkatkan kreativitas anak dalam enam lingkup perkembangan yang sangat penting untuk tumbuh kembang anak. Hal ini terbukti dari perbandingan tingkat kreativitas anak pada sebelum tindakan atau prasiklus dengan kreativitas setelah pelaksanaan siklus I yang bisa dilihat pada skor rata-rata pada masing-masing lingkup perkembangan. Pertemuan 1 untuk lingkup perkembangan nilai agama dan moral mendapat skor rata-rata 22 dengan prosentase $91,66 \%$, sosial emosional mendapat skor ratarata 13 dengan prosentase $54,16 \%$, kognitif mendapat skor rata-rata 22 dengan prosentase $83,33 \%$, bahasa mendapat skor rata-rata 18 dengan prosentase $75 \%$, fisik motorik mendapat skor rata-rata 24 dengan prosentase $100 \%$, dan seni mendapat skor rata-rata 12 dengan prosentase 50\%. Sedangkan untuk pertemuan kedua, secara keseluruhan untuk untuk lingkup perkembangan nilai agama dan moral mendapat skor rata-rata 23 dengan prosentase $100 \%$, sosial emosional mendapat skor rata-rata 19 dengan prosentase $82,60 \%$, kognitif mendapat skor rata-rata 22 dengan prosentase $95,65 \%$, bahasa mendapat skor rata-rata 20 dengan prosentase $86,95 \%$, fisik motorik mendapat skor rata-rata 23 dengan prosentase $100 \%$, dan seni mendapat skor ratarata 19 dengan prosentase $82,60 \%$.

\section{b) Temuan Siklus II}

Pada siklus II keterlaksanaan pembelajaran dengan menggunakan playdoh secara keseluruhan berjalan dengan baik, mulai dari kegiatan awal, kegiatan inti sampai kegiatan penutup. Pada siklus II ini pembelajaran sudah jauh lebih baik dengan siklus I, karena antara lingkup perkembangan yang satu dengan yang lain sudah tidak terpecah, karena sudah merata nilai rata-rata dan prosentase antara lingkup perkembangan yang satu dengan yang lain. Pembelaajaran di cocokan dengan tema, sehingga anak-anak lebih fokus dalam membuat hasil karya karena telah ditentukan oleh tema pembelajaran.

Aktivitas dan fokus anak-anak pada proses belajar sudah lebih baik. Data hasil observasi aktivitas belajar anak pada pertemuan pertama dan pertemuan kedua secara keseluruhan mulai dari kegiatan awal, yaitu mengikuti kegiatan berdoa sebelum kegiatan, kegiatan 
percakapan tentang playdoh, kegiatan motorik kasar, semua anak aktif dan bersemangat. Kemudian kegiatan inti yang terdiri dari kegiatan mengamati playdoh, tanya jawab, mengumpulkan informasi tentang playdoh, menalar, mengkomunikasikan, mengerjakan kegiatan yang disiapkan dalam kelompok kecil, anak-anak sudah lebih aktif. Pada kegiatan akhir yaitu berdiskusi serta berdoa, semua anak terlibat aktif. Pertemuan pertama mendapat skor rata-rata 20,92 dengan prosentase $90,19 \%$, sedangkan pada pertemuan kedua mendapat skor rata-rata 20,28 dengan prosentase 96,95\%. Artinya aktivitas anak secara keseluruhan apabila di rata-rata mendapat skor 20,6 dengan prosentase $93,57 \%$ siswa aktif melaksanakan aktivitas belajar.

Pengunaan playdoh untuk meningkatkan kreativitas dapat membantu anak dalam proses belajar mengajar. Pada siklus II ini kreativitas anak meningkat dibanding pada siklus I. Hal ini ditunjukan dari data observasi hasil belajar anak selama pelaksanaan tindakan siklus II pertemuan pertama secara keseluruhan untuk lingkup perkembangan nilai agama dan moral mendapat skor rata-rata 23 dengan prosentase $100 \%$, sosial emosional mendapat skor ratarata 23 dengan prosentase $100 \%$, kognitif mendapat skor rata-rata 23 dengan prosentase $100 \%$, bahasa mendapat skor rata-rata 23 dengan prosentase $100 \%$, fisik motorik mendapat skor rata-rata 23 dengan prosentase $100 \%$, dan seni mendapat skor rata-rata 23 dengan prosentase $100 \%$. Sedangkan untuk pertemuan kedua, secara keseluruhan untuk untuk lingkup perkembangan nilai agama dan moral mendapat skor rata-rata 21 dengan prosentase $100 \%$, sosial emosional mendapat skor rata-rata 21 dengan prosentase $100 \%$, kognitif mendapat skor rata-rata 21 dengan prosentase $100 \%$, bahasa mendapat skor ratarata 21 dengan prosentase $100 \%$, fisik motorik mendapat skor rata-rata 21 dengan prosentase $100 \%$, dan seni mendapat skor rata-rata 21 dengan prosentase $100 \%$.

Pengunaan playdoh untuk meningkatkan kreativitas dapat membantu anak dalam proses belajar mengajar. Pada siklus II ini kreativitas anak lebih meningkat dibanding kreativitas anak pada siklus I. Siklus I pertemuan 1 untuk lingkup perkembangan nilai agama dan moral mendapat skor rata-rata 22 dengan prosentase $91,66 \%$, sosial emosional mendapat skor ratarata 13 dengan prosentase $54,16 \%$, kognitif mendapat skor rata-rata 22 dengan prosentase $83,33 \%$, bahasa mendapat skor rata-rata 18 dengan prosentase $75 \%$, fisik motorik mendapat skor rata-rata 24 dengan prosentase $100 \%$, dan seni mendapat skor rata-rata 12 dengan prosentase $50 \%$. Untuk pertemuan kedua, secara keseluruhan untuk untuk lingkup perkembangan nilai agama dan moral mendapat skor rata-rata 23 dengan prosentase $100 \%$, sosial emosional mendapat skor ratarata 19 dengan prosentase $82,60 \%$, kognitif mendapat skor rata-rata 22 dengan prosentase $95,65 \%$, bahasa mendapat skor rata-rata 20 dengan prosentase $86,95 \%$, fisik motorik mendapat skor rata-rata 23 dengan prosentase $100 \%$, dan seni mendapat skor rata-rata 19 dengan prosentase $82,60 \%$.

Sedangkan untuk hasil belajar anak pada siklus II pada pertemuan pertama secara keseluruhan untuk lingkup perkembangan nilai agama dan moral mendapat skor rata-rata 23 dengan prosentase $100 \%$, sosial emosional mendapat skor rata-rata 23 dengan prosentase $100 \%$, kognitif mendapat skor rata-rata 23 dengan prosentase $100 \%$, bahasa mendapat skor rata-rata 23 dengan prosentase $100 \%$, fisik motorik mendapat skor rata-rata 23 dengan prosentase $100 \%$, dan seni mendapat skor rata-rata 23 dengan prosentase $100 \%$. Untuk pertemuan kedua, secara keseluruhan untuk untuk lingkup perkembangan nilai agama dan moral mendapat skor rata-rata 21 dengan prosentase $100 \%$, sosial emosional mendapat skor rata-rata 21 dengan prosentase $100 \%$, kognitif mendapat skor rata-rata 21 dengan prosentase $100 \%$, bahasa mendapat skor rata-rata 21 dengan prosentase $100 \%$, fisik motorik mendapat skor rata-rata 21 dengan prosentase $100 \%$, dan seni mendapat skor rata-rata 21 dengan prosentase $100 \%$.

\section{b. Pembahasan}

Dalam pengembangan kreativitas anak, peran keseluruhan komponen meliputi guru, orangtua dan masyarakat harus bereran aktif dalam mengenalkan kepekaan terhadap 
lngkungan sekitar anak. Orang tua dan guru harus menjawab dengan cara menyediakan sarana yang dapat merangsang anak untuk berpikir lebih luas, dalam hal ini peneliti menggunakan playdoh untuk mengembangkan daya imajinasi, mengeluarkan ide yang ada, yang mungkin sebelumnya ide tersebut terkurung karena tidak adanya pemicu yang bisa membuat anak tersebut mengeluarkan kemampuan terbaiknya.

Untuk meningkatkan kreativitas anak, diperlukan sesuatu yang bisa memberikan stimulus yang bisa merangsang ide dan pemikiran yang dimiliki anak-anak, berupa suatu permainan yang sudah jarang digunakan di sekolah tersebut. Playdoh, juga berfungsi sebagai alar permainan edukatif yang meningkatkan motorik halus serta kreatif seni anak-anak.

Berdasarkan penelitian terdahulu (Dewi, 2011; Rohmah, 2014) dapat disimpulkan bahwa permainan playdoh dapat meningkatkan kreativitas anak. Hasil penelitian ini juga dapat meningkatkan hasil belajar anak dalam 6 lingkup perkembangan di TK GMIM Bethesda Sawangan. Kreativitas anak sebelum penelitian atau prasiklus yang dilakukan pada tanggal 22 agustus 2016, diperoleh skor $37,49 \%$. Setelah penelitian pada siklus I diperoleh skor rata-rata 83,49\%. Pada siklus II meningkat menjadi $90 \%$. Peningkatan kreativitas dapat dilihat dalam diagram 5.1 berikut.

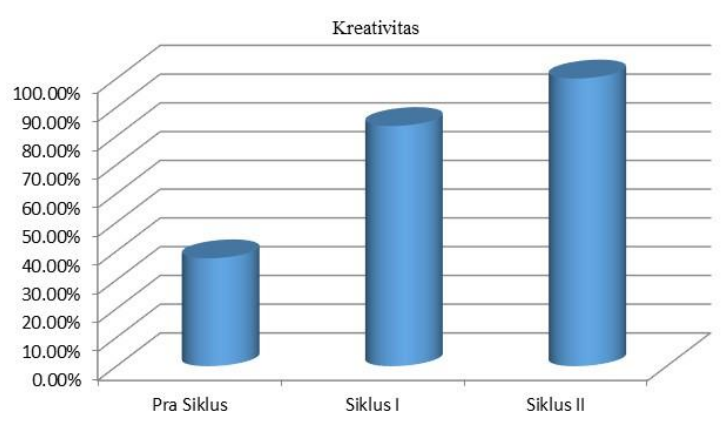

Gambar 1. Peningkatan Kreativitas Melalui Permainan Playdoh

Gambar 1 menunjukan bahwa kreativitas anak dari prasiklus mencapai skor rata-rata $37,49 \%$, meningkat menjadi $83,49 \%$ pada siklus I, dan pada siklus II meningkat menjadi 100\%. Dengan demikian permainan playdoh

Jurnal Ilmu Sosial dan Pendidikan dapat meningkatkan kreativitas anak terutama dalam 6 lingkup perkembangan yang terdiri dari nilai agama dan moral, sosial emosional, kognitif, bahasa, fisik motorik, dan seni. Kelebihan dari permainan playdoh yaitu: (1) mampu menghubungkan ke enam lingkup perkembangan, (2) aktivitas belajar sambil bermain lebih menyenangkan (3) playdoh mudah dibersihkan, tidak terlalu berminyak, (4) anak menjadi aktif dan tidak mudah bosan dalam belajar, (5) mampu mendorong kreativitas anak dalam menciptakan suatu karya seni, (6) memudahkan anak untuk menyerap pembelajaran, (7) mampu mengembangkan 6 lingkup perkembangan di TK.

Sedangkan kelemahan dari permainan playdoh ini yaitu karena peneliti dalam mengejar waktu penelitian yang hampir mencapai batas kelulusan, maka peneliti membeli playdoh yang sudah jadi (tersedia di toko) dengan harga yang mahal. Lebih lanjut, berdasarkan data yang dikumpulkan pada 6 lingkup perkembangan anak dapat disimpulkan bahwa, kreativitas dapat meningkat dengan bantuan permainan playdoh. Hal ini terbukti dari skor rata-rata siklus I diperoleh 83,49\%, meningkat menjadi $100 \%$ pada siklus II, artinya bahwa dari siklus I ke siklus II mengalami peningkatan sebanyak $16,51 \%$

\section{KESIMPULAN}

Berdasarkan hasil penelitian tindakan kelas, maka dapat disimpulkan bahwa bermain playdoh di TK GMIM Bethesda Sawangan tahun pelajaran 2019/2020 dapat meningkatkan kreativitas anak. Hal ini dibuktikan dengan adanya peningkatan hasil persentase kreativitas anak yang dicapai sesuai dengan harapan peneliti. Hal ini dapat terlihat dari peningkatan presentase nilai rata-rata pada siklus I pertemuan pertama, pada 6 lingkup perkembangan yaitu lingkup perkembangan nilai agama dan moral mendapat skor rata-rata 22 dengan prosentase 91,66\%, sosial emosional mendapat skor rata-rata 13 dengan prosentase $54,16 \%$, kognitif mendapat skor rata-rata 22 dengan prosentase $83,33 \%$, bahasa mendapat skor rata-rata 18 dengan prosentase 
$75 \%$, fisik motorik mendapat skor rata-rata 24 dengan prosentase $100 \%$, dan seni mendapat skor rata-rata 12 dengan prosentase $50 \%$.

Untuk pertemuan kedua, secara keseluruhan untuk untuk lingkup perkembangan nilai agama dan moral mendapat skor rata-rata 23 dengan prosentase $100 \%$, sosial emosional mendapat skor ratarata 19 dengan prosentase $82,60 \%$, kognitif mendapat skor rata-rata 22 dengan prosentase $95,65 \%$, bahasa mendapat skor rata-rata 20 dengan prosentase $86,95 \%$, fisik motorik mendapat skor rata-rata 23 dengan prosentase $100 \%$, dan seni mendapat skor rata-rata 19 dengan prosentase $82,60 \%$.

Pada siklus 2 peningkatan prosentase meningkat jauh dibandingkan siklus I, terlihat pada peningkatan 6 lingkup perkembangan sebagai berikut, lingkup perkembangan nilai agama dan moral mendapat skor rata-rata 23 dengan prosentase $100 \%$, sosial emosional mendapat skor rata-rata 23 dengan prosentase $100 \%$, kognitif mendapat skor rata-rata 23 dengan prosentase $100 \%$, bahasa mendapat skor rata-rata 23 dengan prosentase $100 \%$, fisik motorik mendapat skor rata-rata 23 dengan prosentase $100 \%$, dan seni mendapat skor rata-rata 23 dengan prosentase $100 \%$.

Untuk pertemuan kedua, secara keseluruhan untuk untuk lingkup perkembangan nilai agama dan moral mendapat skor rata-rata 21 dengan prosentase $100 \%$, sosial emosional mendapat skor ratarata 21 dengan prosentase $100 \%$, kognitif mendapat skor rata-rata 21 dengan prosentase $100 \%$, bahasa mendapat skor rata-rata 21 dengan prosentase $100 \%$, fisik motorik mendapat skor rata-rata 21 dengan prosentase $100 \%$, dan seni mendapat skor rata-rata 21 dengan prosentase $100 \%$.

\section{SARAN}

- Berdasarkan hasil penelitian yang telah dilakukan maka peneliti mengajukan saran terhadap pihak sekolah dan guru. Bagi pihak sekolah hendaknya menyediakan media yang lebih kekinian, seperti permainan playdoh sehingga anak-anak dapat lebih terlatih kreativitasnya untuk daya pikir dan daya imajinasi anak. Hal

tersebut dikarenakan pembelajaran dengan menggunakan permainan playdoh hendaknya diterapkan di sekolah, sehingga pembelajaran dapat menjadi menyenangkan karena di samping membantu daya pikir anak melalui berkreasi melalui bentuk, juga anak-anak menjadi antusias dan bersemangat sehingga menghilangkan kejenuhan.

- Saran selanjutnya yaitu bagi pihak guru untuk dapat membimbing dan memberikan motivasi serta memfasilitasi anak untuk meningkatkan kemampuan kreativitas, sehingga kreativitasnya dapat meningkat dan tidak terlambat. Lebih lanjut belajar hendaknya dilakukan seraya bermain sehingga anak merasa senang, antusias, dalam mengerjakan tugas yang diberikan oleh guru. Langkah terakhir yang dapat dilakukan yaitu dengan membuat pelajaran yang menarik, sehingga anak-anak menjadi antusias dalam melakukan kegiatan belajar mengajar.

\section{DAFTAR PUSTAKA}

Ahmad Susanto. 2013. Teori Belajar dan Pembelajaran di Sekolah Dasar. Jakarta: Kencana Prenadamedia Group

Depdiknas. 2007. Pedoman Pembelajaran Bidang Pengembangan Kognitif di Taman Kanak-Kanak. Jakarta: Dirjen Mapendasmen Direktorat Pembinaan TK dan SD.

Fathimah, Siti, Sangputri Sidik, and Rahmania Rahman. 2020. Google Docs Sebagai Solusi Pengerjaan Tugas Kelompok Dalam Pembelajaran Daring Di Tengah Pandemi Covid 19. Ilmu Sosial Dan Pendidikan 4(3):272-79

Kalsum, Ummi, Fadillah, and Dian Miranda. 2016. Peningkatan Kreativitas Anak Melalui Sentra Seni Pada Usia 5-6 Tahun di Taman Kanak-Kanak Surya. Jurnal Pendidikan dan Pembelajaran Khatulistiwa 5(5)

Martani, Wisjnu. 2012. Metode Stimulasi dan Perkembangan Emosi Anak Usia Dini. Jurnal Psikologi 39(1):112-120

Partiyem, 2014. Meningkatkan kemampuan motorik halus dengan kegiatan bermain 
plastisin kelompok B PAUD Istiqomah

Sumber Bening Kecamatan Selupu

Rejang. Tesis, Universitas Bengkulu.

Putro, Khamim Zarkasih. 2016. Mengembangkan Kreativitas Anak Melalui Bermain. APLIKASIA: Jurnal Aplikasi Ilmu-ilmu Agama 16(1):19-27

Qudsyi, Hazhira. 2010. Optimalisasi Pendidikan Anak Usia Dini Melalui Pembelajaran Yang Berbasis Perkembangan Otak. Buletin Psikologi 18(2):91-111

Rohmah, Zustina Veby. 2014. Upaya meningkatkan kreativitas anak melalui permainan plastisin pada anak playgroup di paud nur rohmah plupuh sragen tahun ajaran 2013/2014. Skripsi thesis, Universitas Muhammadiyah Surakarta.

Sujiono, Y., N. 2008. Metode Pengembangan Kognitif. Jakarta: Universitas Terbuka.

Triantoro, Safaria, 2005, Creativity Quatiant, Panduan Mencetak Anak Super Kreatif, Jogjakarta: Platinum Diqlossia Media Baru.

Wikaningtyas, Diah Utami. 2014. Peningkatan Kemampuan Motorik Halus melalui Kegiatan Membentuk dengan berbagai Media pada Anak Kelompok A TK Aba Panggeran Sleman". Skripsi, Universitas Negeri Yogyakarta. 